\title{
Community composition and diet of fishes as a function of tidal channel geomorphology
}

\author{
Tammie A. Visintainer ${ }^{1,4, *}$, Stephen M. Bollens ${ }^{2}$, Charles Simenstad ${ }^{3}$ \\ ${ }^{1}$ Department of Biology and Romberg Tiburon Center for Environmental Studies, San Francisco State University, \\ 3152 Paradise Drive, Tiburon, California 94920, USA \\ ${ }^{2}$ School of Biological Sciences, Washington State University Vancouver, 14204 NE Salmon Creek Avenue, Vancouver, \\ Washington 98686-9600, USA \\ ${ }^{3}$ Wetland Ecosystem Team, School of Aquatic and Fishery Sciences, Box 355020, University of Washington, Seattle, \\ Washington 98195-5020, USA \\ ${ }^{4}$ Present address: Bodega Marine Laboratory, PO Box 247, Bodega Bay, California 94923, USA
}

\begin{abstract}
We examined how channel system order and complexity influence fish community composition, abundance, and diet, by comparing first- through fourth-order channel systems at China Camp Marsh, San Francisco Estuary, California, USA. We sampled 6 channel systems (with replicates of the second- and fourth-order systems) bimonthly from July 2001 to May 2002 using modified fyke nets. We examined the diet of the 3 most common species that occurred consistently over time (seasonally): Atherinops affinis, Menidia beryllina, and Leptocottus armatus. Low-order (first- and second-order) systems supported higher densities of Gambusia affinis and Lucania parva. High-order (third- and fourth-order) systems supported greater species richness and densities of juveniles, including Clupea pallasi, than low-order systems. Prey taxa richness was greater for $M$. beryllina and lower for $L$. armatus in the first-order system. There was a positive correlation between high-order channel systems and mean stomach fullness scores for $L$. armatus, and $M$. beryllina had greater short-term consumption rates in high-order channel systems. Habitat heterogeneity, and specifically the presence of both low- and high-order channel systems, is necessary to accommodate early life stages, species-specific dietary requirements, and enhanced species richness of fishes at China Camp Marsh. Based on our results, we recommend that the processes and landscape scales that promote channel formation be considered in future salt marsh restoration projects.
\end{abstract}

KEY WORDS: Channel system order - Tidal marsh · Fish ecology · Community composition · Diet · Wetland restoration

Resale or republication not permitted without written consent of the publisher

\section{INTRODUCTION}

Considerable research attention has been paid to responses of nekton to tidal marsh edge, elevation, and surface (Baltz et al. 1993, Rozas \& Reed 1993, Kneib \& Wagner 1994, Minello et al. 1994, Peterson \& Turner 1994, Rozas \& Zimmerman 2000, West \& Zedler 2000), yet few (Hettler 1989, Desmond 1996, Desmond et al. 2000) have addressed marsh geomorphology, such as tidal channel complexity. Nekton play important roles in marsh ecosystems as both prey and predators (Baltz et al. 1993, Rozas \& Reed 1993, Kneib \& Wagner 1994,
Minello et al. 1994, Peterson \& Turner 1994, Rozas \& Zimmerman 2000, Talley 2000, West \& Zedler 2000), and habitat heterogeneity is an important factor for predicting species richness and abundance of fishes (Szedlmayer \& Able 1996). Adult and juvenile nekton benefit from the high productivity of the flooded marsh surface (Minello \& Zimmerman 1992, Rozas 1992, Rozas \& Minello 1998) and act as critical vectors in the transport of nutrients and energy (Kneib 1997, West \& Zedler 2000) in the 'trophic relay' that horizontally translocates intertidal production across boundaries within the marsh system and along the estuarine gradi- 
ent (Kneib 2000). The relationship of tidal marsh geomorphology to nekton productivity is particularly germane to restoration of tidal marshes.

Marsh channels provide corridors from open water to the intertidal marsh (Rozas \& Zimmerman 2000), and use of these regions by fishes is defined, in part, by species-specific responses to the physical characteristics of the marsh channels. Geomorphic features such as penetration and total edge of tidal channels influence the extent of access for fishes into various habitats as well as the interface along which they feed (Simenstad \& Cordell 2000). Most nekton species have been shown to select areas with low-elevation marsh edge (Peterson \& Turner 1994, Rozas \& Zimmerman 2000) and, in a Louisiana estuary, species richness was shown to be significantly affected by distance from the marsh edge (Baltz et al. 1993). Species-specific responses have been noted in relation to channel depth and bank slope in southern California natural and constructed tidal salt marshes (Williams \& Zedler 1999), with implications for consumption and mortality rates due to predation (McIvor \& Odum 1988).

Tidal channel order is a common surrogate for channel complexity and other scalars associated with tidal geometry relationships (Williams et al. 2002). A channel is progressively ordered by the number of bifurcations upstream of it, whereby first-order channels have no bifurcations (Horton 1945, Strahler 1964), and the entire channel system is numbered by the highest channel order it contains. Higher-ordered channel systems are generally larger. Comparisons in channel order can be made within a single system, or among separate systems of different orders. The uppermost reaches of channel systems provide nursery grounds for early life stages of fishes, whereas downstream sections provide low-tide refuge for larger nekton using adjacent subtidal regions (Weinstein 1979, Rozas \& Zimmerman 2000). First-order channels are highly productive, providing low predation pressure, reduced competition, diminished flow velocities, lower temperatures, and an extensive food supply for large numbers of juvenile fishes (Shenker \& Dean 1979, Bozeman \& Dean 1980, Rozas \& Hackney 1984, Rozas \& Odum 1987b, Gray et al. 2002). Rozas et al. (1988) found that small first-order channels (coined 'rivulets') contained a significantly higher biomass of fishes than larger adjacent channels and appeared to be the preferred pathway for marsh surface access.

Fish community composition is typically correlated with habitat structure and complexity (Rozas \& Odum 1987a, McIvor \& Odum 1988, Rozas et al. 1988, Baltz et al. 1993, Szedlmayer \& Able 1996, Jordan et al. 1998, Meng \& Powell 1999). Therefore, fishes are considered good indicators of habitat function in natural tidal wetland systems, and are desired components in re- storation projects. Moyle et al. (1986) and Meng et al. (1994) found that native fishes are more common in small sloughs than in larger sloughs in Suisun Marsh, San Francisco Estuary, whereas introduced species show no slough size relationship. Species richness has been shown to differ between channel order systems in southern California salt marshes (Desmond 1996, Desmond et al. 2000), and densities of fishes have been observed to decrease with increasing creek order (Weinstein 1979, Rozas \& Odum 1987a, Hettler 1989).

Restoring coastal wetlands is a pervasive goal, and although progress has been made toward understanding the dynamic processes governing tidal wetland geomorphology (Williams \& Orr 2002, Orr et al. 2003), little information exists on how structural characteristics such as marsh size and complexity affect fish performance. Channel geomorphology in restored tidal marshes, particularly for constructed (i.e. man-made) marshes, is distinctly different from that in natural marshes. Natural marshes often contain channels of lower order with narrow, steeply sloped banks, whereas created channels have broad, gradually sloping banks. It has been suggested that these differences affecting proximity to vegetated edge help determine the assemblage composition of fishes (Williams \& Zedler 1999). Specifically, created marshes in southern California lacked small size classes of certain species, which was attributed by Talley (2000) to lack of shallow water habitat and low-order channels in these regions. Since low-order channels allow access to more productive, low elevation intertidal areas, the lack of such channels in constructed marshes may reduce densities of certain nekton species (Havens et al. 1995, Zedler et al. 1997). This concept reinforces the submission that estuarine landscape structure and scale must be considered to properly restore marsh habitats for fish production (Simenstad et al. 2000)

Our understanding of nekton use of coastal marshes and channels comes primarily from studies in North American Atlantic and Gulf coast tidal salt marshes. Estuarine wetlands of the North American Pacific coast differ from Atlantic coast estuaries in that they are generally smaller in size, support a smaller percentage of commercially important species, have greater tidal ranges, and sustain higher seasonal and interannual variations in precipitation and runoff (Williams \& Zedler 1999). San Francisco Estuary is an intensively studied system (Moyle et al. 1986, Meng et al. 1994, Coats et al. 1995, Chotkowski 1999, Simenstad et al. 1999, Hieb \& DeLeon 2000, Williams \& Orr 2002, Williams et al. 2002, Orr et al. 2003), yet few studies have addressed ecological processes, or compared dendritic tidal channel order systems (Coats et al. 1995, Desmond 1996, Desmond et al. 2000), and none have examined fish diets (Brown 2003). As in many coastal regions, the increasing number of restoration projects 
in the San Francisco Estuary, demands an improved understanding of the relationship between channel system order and fish utilization to ensure proper restoration design and management of these areas.

We examined how channel system order is related to fish community composition, abundance, and diet. We tested the null hypothesis that channel system order would have no effect on (1) fish community composition, (2) relative abundance, or (3) fish diet, by comparing fish use of first- through fourth-order channel systems in one of the largest natural tidal wetlands in the San Francisco Estuary.

\section{MATERIALS AND METHODS}

Study period and site. Fish sampling occurred bimonthly from July 2001 to May 2002 in 6 channel systems at China Camp State Park, San Pablo Bay (San Francisco Estuary), approximately 20 miles (32.19 km) north of San Francisco, California. China Camp is a 38.2 ha ancient and centennial salt marsh (Williams \& Orr 2002) that historically has experienced minimum anthropogenic impact over time. The channel systems sampled were located at the west end of China Camp $\left(38^{\circ} 00.943^{\prime} \mathrm{N}, 122^{\circ} 30.010^{\prime} \mathrm{W}\right)$ adjacent to the mouth of Gallinas Creek (Fig. 1). Due to a difference in time of formation, the marsh progresses from centennial to ancient marsh, proceeding from the bay to the interior. A mixed semidiurnal tide inundates the marsh channels daily. Pickleweed Salicornia virginica dominates the marsh-plain vegetation, with Spartina foliosa bordering tidal channels and Bolboschoenus robustus growing along the marsh-bay edge. China Camp receives freshwater input from the Sacramento and San Joaquin rivers to the east as well as local rain runoff from uplands and Gallinas Creek in the winter months. Freshwater input during our sampling peaked in January 2002, indicated by significantly lower salinity (16.8 psu) compared to higher salinity (29.5 psu) in October 2001. We sampled on spring tides when the average high tide was $1.8 \mathrm{~m}(5.9 \mathrm{ft})$ mean lower low water (MLLW) and the average low tide was $0.15 \mathrm{~m}$ (0.5 ft) MLLW (NOAA-predicted tides). The sampling year was divided into a wet season comprising January, March, and May, and a dry season comprising July, October, and November, because seasonal freshwater outflows were significantly different $(F=$ 21.455, df $=1, \mathrm{p}<0.001$ ) (California Department of Water Resources - http://cdec.water.ca.gov).

Fish sampling. We sampled 6 channel systems at China Camp Marsh, which comprised 3 simple channel systems (first-order and second-order) and 3 complex channel systems (third- and fourth-order) with replicates of the second- and fourth-order systems, ordered according to Horton (1945) as modified by Strahler (1964). Fourth-order channels are the largest systems present at China Camp. We sampled 2 channels per day over a $3 \mathrm{~d}$ period during the spring low tides of each particular sampling month. Complete dewatering occurred in all but 1 channel.

Fishes were sampled with modified nylon mesh fyke nets that were deployed as tidal channel trap (block) nets, which have been found to be an effective sampling method in a variety of estuarine tidal channel ecosystems (e.g. Miller \& Simenstad 1997, Mathieson et al. 2000, Gray et al. 2002, Barletta et al. 2003, Bottom et al. 2005). The fyke nets were composed of a $3.2 \mathrm{~mm}$

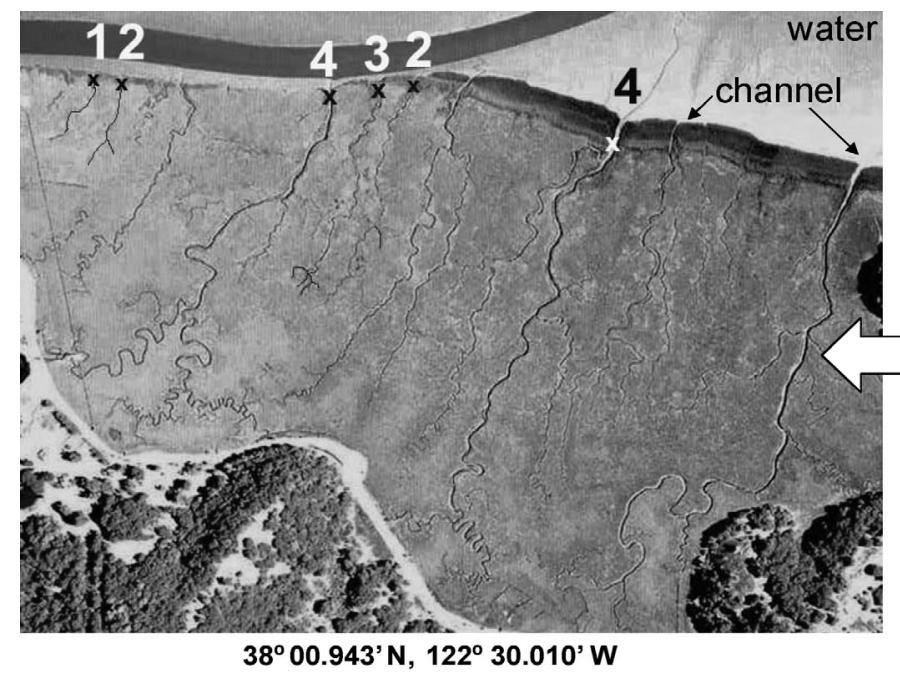

Fig. 1. Site map of first- through fourth-order channel systems sampled at China Camp Marsh, San Francisco Estuary. Numbers represent channel system order, and crosses mark approximate placement of fyke nets in each channel

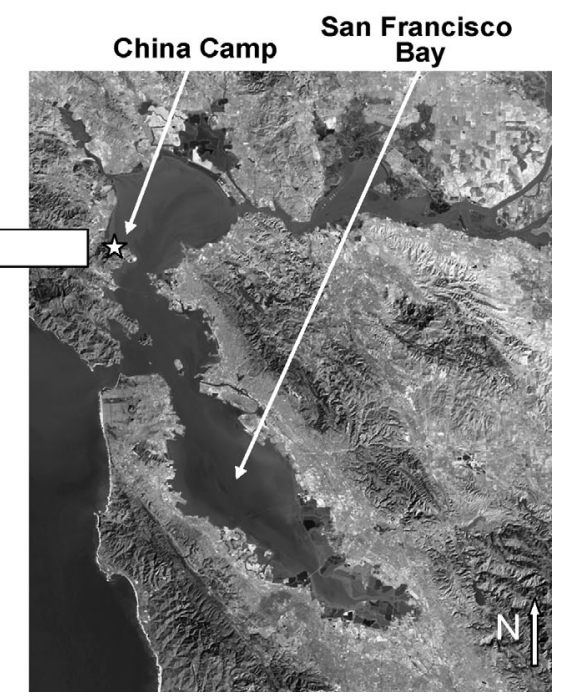


(1/8 inch) mesh mouth, body, and live trap in the cod end, as well as adjustable $6.4 \mathrm{~mm}$ (1/4 inch) mesh wings that attached to the net mouth and extended to the sides of each channel and to the marsh edge. Nets were placed across each channel approximately $10 \mathrm{~m}$ upstream of the channel mouth. Nets were set during the post-flood slack tide and recovered at the post-ebb slack tide. Fishes were removed from the live trap throughout the ebbing cycle. For each channel system and sampling period, we measured temperature and salinity (YSI Yellow Spring Instrument Co., Model 85) at the surface and bottom of each channel at the location of the fyke net, immediately after nets were deployed at slack tide following the flood tide.

One fourth-order channel system did not dewater completely at low tide (approximately $100 \mathrm{~m}$ of water remained) and, therefore, required a block net system during sampling. We secured 2 block nets ( 20 m apart) perpendicularly across the channel upstream $(\sim 10 \mathrm{~m})$ of the fyke net at slack low tide. The blocked region ( $20 \mathrm{~m}$ long, $1.5 \mathrm{~m}$ wide) was seined from bank to bank using a $3.2 \mathrm{~mm}$ (1/8 inch) mesh seine net. Passes were made with the seine net until the abundance of fishes captured substantially decreased (i.e. less than 3 fishes per haul). Total fish abundance was estimated by plotting the number of fishes caught in each pass against the sum of all previous catches and determining the total number expected in the population from where the extended line crossed the $x$-axis (Seber \& LeCren 1967). The total number expected was multiplied by the distance of remaining water (in meters) and added to the total fyke catch for that channel.

Fishes were identified to species, counted, weighed to the nearest $0.01 \mathrm{~g}$, measured (fork length when applicable, or total length) to the nearest millimeter, and released. When a large catch was obtained (this occurred approximately $50 \%$ of the time), a 'random' subsample of 50 fish of each species was selected by hand, measured and weighed in the field. We retained species that could not be identified in the field as well as subsamples of the most prevalent species for later stomach content analyses. Retained specimens were anesthetized with MS-222 (tricaine methanesulfonate), preserved in a $10 \%$ formalin solution, and brought back to the laboratory (Romberg Tiburon Center for Environmental Studies) for later analyses. Fish abundances were normalized to density by marsh edge (m) and volume $\left(\mathrm{m}^{3}\right)$ for comparison across channel systems.

Fish diet analysis. We examined the stomach contents of topsmelt Atherinops affinis, inland silversides Menidia beryllina, and Pacific staghorn sculpin Leptocottus armatus. These species represented a pelagic omnivore, a pelagic planktivore, and a demersal omnivore, respectively, and were the 3 most common species consistently present over time (seasonally). Stom- ach contents of $A$. affinis (20-29 mm, 60-69 mm and 50-89 mm size classes) were examined from July, October, and November 2001 samples, respectively. Stomach contents were examined for $M$. beryllina $(60$ to $69 \mathrm{~mm}$ size class) collected in October and November 2001 and L. armatus collected in January (20 to $39 \mathrm{~mm}$ ), March (20 to $49 \mathrm{~mm}$ ), and May 2002 (60 to $89 \mathrm{~mm}$ ). For each species, the forestomach was removed and the contents extracted, blotted dry and weighed (wet) to the nearest $1 \mu \mathrm{g}$. Percent fullness was assessed and assigned a relative index of fullness ( $0=$ empty, $1=25 \%$ full, $2=50 \%$ full, $3=75 \%$ full, $4=100 \%$ full). Similarly, stomach content digestion was assessed and assigned to a relative index of digestion ( $0=$ all digested, $1=25 \%$ digested, $2=50 \%$ digested, $3=75 \%$ digested, $4=$ $100 \%$ digested). Prey items were sorted, enumerated and identified to the lowest feasible taxonomic category (usually to species) using a dissecting microscope. Each prey taxon was weighed to the nearest $1 \mu \mathrm{g}$. Stomach content weight was normalized by dividing each stomach weight by the individual fish weight (termed the 'normalized stomach content weight'), assuming that fish of all sizes within a species have the same relative stomach size.

Channel geomorphology. Channel lengths were estimated using a 1995 aerial photograph rubbersheeted onto a USGS digital ortho-quadrangle (DOQ) $600 \times 400$ pixel 1993 base map with $4 \mathrm{~m}$ resolution. A geographically corrected image with $1 \mathrm{~m}$ resolution was created and imported into ERDAS IMAGINE 8.6 ${ }^{\circledR}$ software for length estimations. All segments of each channel system were measured using the ERDAS IMAGINE 8.6 ${ }^{\circledR}$ measuring tool and proportions of each order present in the system were calculated. Channel edge was estimated as twice the channel length (in meters) and represented one method used to transform fish densities (no. $\mathrm{m}^{-1}$ ) for each channel system. Channel elevations were estimated at the mouth of each channel system using a local benchmark and a Trimble 5700 real-time kinematic (RTK) Global Positioning System (GPS). Bank slopes (rise:run) were estimated for each channel system by measuring from the lowest channel elevation (thalweg) to the top of each bank. Tidal inundation regimes were estimated using Tideminer ${ }^{\circledR}$ Version 3.0 based on the relationship of the NOAA-predicted tides for Gallinas Creek and channel and marsh plain elevations. AutoCAD was used to scale and georeference an aerial photo of the channels that had been overlayed onto a DOQ. This scaled aerial photo was then used to estimate drainage area for each channel system, using Arcview GIS $3.2^{\circledR}$. Drainage areas were used to calculate tidal prisms (TPs) using the hydraulic geometry equation $\mathrm{TP}\left[\mathrm{m}^{3}\right]=935 \times(\text { marsh area }[\text { ha }])^{1.17}$ (Williams et al. 2002). These TPs were combined with our catch data to yield a second estimate of relative fish density $\left(\right.$ no. $\mathrm{m}^{-3}$ ) for each 
Table 1. Characteristics of 6 channels sampled at China Camp Marsh, San Francisco Estuary. MHHW: mean higher high water

\begin{tabular}{|c|c|c|c|c|c|c|}
\hline \multirow{2}{*}{ Parameter } & \multicolumn{6}{|c|}{ Channel order } \\
\hline & 1 & 2 & 2 & 3 & 4 & 4 \\
\hline Length (m) & 130.6 & 158.4 & 408.4 & 456.5 & 2787.3 & 3357.0 \\
\hline Edge (m) & 261.2 & 316.7 & 816.7 & 912.9 & 5574.6 & 6714.0 \\
\hline Mean bank slope & 0.7 & 0.5 & 0.4 & 0.4 & 0.3 & 0.3 \\
\hline Mean marsh plain elevation (m) & 1.9 & 1.8 & 1.7 & 1.8 & 2.0 & 1.8 \\
\hline Drainage area (ha) & 0.3 & 0.5 & 1.7 & 1.9 & 11.0 & 13.4 \\
\hline Tidal prism $\left(\mathrm{m}^{3}\right)$ at MHHW & 216.0 & 374.4 & 1738.0 & 1931.0 & 15398.0 & 19462.0 \\
\hline Annual time tidal channel thalwag flooded (\%) & 48.0 & 86.7 & 68.7 & 71.4 & 87.1 & 81.6 \\
\hline Annual time marsh plain flooded $(\%)$ & 2.4 & 3.7 & 5.6 & 3.0 & 1.3 & 3.0 \\
\hline
\end{tabular}

channel. Mean higher high water (MHHW) was estimated as $1.89 \mathrm{~m}(6.21 \mathrm{ft})$. When spring tides were above MHHW, the difference in water height (converted to meters) was multiplied by the drainage area and added to the estimated TP for each channel. We felt that TP and channel edge were the best metrics of fish access and occupation of the marsh. To determine if marsh area as a third metric would be beneficial, we ran linear regressions for (1) TP vs. marsh area $\left(\mathrm{R}^{2}=0.743, \mathrm{p}<0.05\right)$, and (2) marsh edge vs. marsh area $\left(R^{2}=0.927, p<0.01\right)$. We determined that marsh area was autocorrelated with TP and edge, and therefore redundant.

Statistical analyses. Salinity, temperature, and tidal range: We used two 1-way analyses of variance (ANOVA) with months and channel system order as factors (Sokal \& Rohlf 1995) to detect differences in salinity, temperature and tidal ranges.

Community composition: Kendall's coefficient of concordance $(W)$, a nonparametric multi-sample rank correlation statistic, was used to test for similarities in fish communities within sampling months, seasons and orders (Sokal \& Rohlf 1995). Kendall's W ranges from 0 (no association) to 1 (perfect association). The 10 most abundant species for all sampling months were used in determining rank correlations. If concordance results were significant (i.e. indicating similar composition), we pooled data for a given channel over time, or for all channels by month. Kendall's tau rank correlations were used to examine differences in fish densities between pairs of channels using the top 10 species for a given month. A significant result indicates similarity in rank order of abundance; therefore, a lack of significance was interpreted as a significant difference in fish community composition.

Fish abundances: We compared fish density between simple and complex channel systems in 3 ways. We used a 2-way analysis of variance (ANOVA) to test effects of channel system order and season (wet vs. dry) on (1) total fish densities (no. $\mathrm{m}^{-3}$ ) based on TP estimates, and (2) fish densities (no. $\mathrm{m}^{-1}$ ) based on length of channel edge (Sokal \& Rohlf 1995). Student's $t$-tests were run for single species data by combining the low-order channels (first- and second- orders) and the high-order channels (third- and fourth- orders) and eliminating months when the species was not present in any channel (Sokal \& Rohlf 1995). A third estimate of fish density (no. $\mathrm{m}^{-2}$ based on drainage area) was also calculated: statistical results indicated patterns similar to those achieved with TP and edge estimates, and these results are therefore not presented.

Additionally, each channel system was broken down into all individual orders comprising the channel system. The proportion of each order (first, second, third and fourth) present in a particular channel system was calculated using the lengths of segments. Fish densities $\left(\right.$ no. $\mathrm{m}^{-3}$ ), based on TP estimates, were used in combination with channel system order proportions to determine fish use as a function of channel system order. The relationship between species density and channel system order proportions was tested using Pearson's correlation coefficient (Sokal \& Rohlf 1995).

Fish diet: We used 2-way and 1-way analyses of variance (ANOVA) to test for differences in stomach fullness indices, number of prey items per fish, and total stomach content weights, using months and channel system order as factors (Sokal \& Rohlf 1995). A Student's $t$-test was then used to compare low- and high-ordered channels by normalized stomach content weight, number of prey taxa, and stomach fullness scores for all 3 fish species analyzed (Sokal \& Rohlf 1995). In all cases, data from the first-order and 2 second-order channels were combined into a low-order channel group and data from the thirdorder and 2 fourth-order channels were combined into a high-order group.

\section{RESULTS}

\section{Environmental variables}

Length of vegetated edge and TP increased, while bank slope decreased with increasing channel system order. Mean marsh plain elevation was lowest in a second-order channel system (Table 1). When broken 
Table 2. Proportion of channel orders comprising each sampled channel at China Camp Marsh. Proportions are based on lengths $(\mathrm{m})$ of each ordered segment

\begin{tabular}{|lcccccc|}
\hline \multirow{2}{*}{ Order } & \multicolumn{6}{c|}{ Channel orders sampled } \\
& \multirow{2}{*}{1} & 2 & 2 & 3 & 4 & 4 \\
& \multirow{2}{*}{1.00} & 0.56 & 0.45 & 0.25 & 0.39 & 0.37 \\
First order & & 0.44 & 0.55 & 0.04 & 0.26 & 0.27 \\
Second order & & & & 0.72 & 0.12 & 0.28 \\
Third order & & & & & 0.24 & 0.08 \\
Fourth order & & & & & & \\
\end{tabular}

down into channel order proportions, first-order proportions were more common than any other proportion in fourth order systems (Table 2).

Average salinity $(F=728.705$, df $=5$, $\mathrm{p}<0.001)$ and temperature $(F=$ 162.607, $\mathrm{df}=5, \mathrm{p}<0.001$ ) were significantly different by month, peaking in July (temperature) and October (salinity) and decreasing to lows in January (Table 3), although neither differed significantly as a function of channel system order (salinity: 1-way ANOVA, $F=0.008, \mathrm{df}=3, \mathrm{p}=0.99$; temperature: $F=0.414, \mathrm{df}=3, \mathrm{p}=0.744)$. Tidal range differed significantly as a function of month $(F=15.927$, df $=5$, p $<0.001)$, but not as a function of channel system order. Average high and low tides during the sampling period were $1.8 \mathrm{~m}$ $( \pm 0.6)$ and $-0.1 \mathrm{~m}( \pm 0.0)$, respectively.

\section{Fish community composition}

From the 6 channel systems consisting of 4 different orders we collected 13308 fishes comprising 22 different species (Table 4). Of the total catch, $98.8 \%$ was composed of 10 species, comprising topsmelt Atherinops affinis
(50.2\%), Pacific staghorn sculpin Leptocottus armatus (14.9\%), inland silversides Menidia beryllina (13.4\%), northern anchovy Engraulis mordax (6.5\%), yellowfin goby Acanthogobius flavimanus (5.8\%), shimofuri goby Tridentiger bifasciatus (4.5\%), Pacific herring Clupea pallasi $(2.0 \%)$, arrow goby Clevelandia ios $(<1 \%)$, American shad Alosa sapidissima $(<1 \%)$, and white croaker Genyonemus lineatus (<1\%). Native fish species constituted between 78.0 and $97.8 \%$ of the total catch, except in November (32.0\%) (Fig. 2). Species composition varied seasonally, with $A$. affinis (81.0\%) and A. flavimanus (14.1\%) dominant in July, A. affinis $(76.9 \%)$ and $T$. bifasciatus $(11.1 \%)$ in October, $M$. beryllina $(61.5 \%)$ and $A$. affinis $(29.5 \%)$ in

Table 4. Number of fishes collected from 6 channels at China Camp Marsh. ${ }^{*}$ : non-native species

\begin{tabular}{|c|c|c|c|c|c|c|c|}
\hline \multirow[t]{2}{*}{ Species } & \multirow[b]{2}{*}{1} & \multicolumn{5}{|c|}{ Channel order } & \multirow[t]{2}{*}{ Total } \\
\hline & & 2 & 2 & 3 & 4 & 4 & \\
\hline Atherinops affinis & 48 & 180 & 603 & 526 & 2388 & 2941 & 6686 \\
\hline Leptocottus armatus & 9 & 24 & 192 & 183 & 101 & 1468 & 1977 \\
\hline Menidia beryllina* & 57 & 173 & 142 & 66 & 606 & 742 & 1786 \\
\hline Engraulis mordax & 0 & 1 & 24 & 7 & 51 & 786 & 869 \\
\hline Acanthogobius flavimanus* & 9 & 30 & 86 & 159 & 252 & 236 & 772 \\
\hline Tridentiger bifasciatus* & 0 & 1 & 6 & 1 & 1 & 589 & 598 \\
\hline Clupea pallasi & 0 & 0 & 2 & 24 & 212 & 22 & 260 \\
\hline Clevelandia ios & 1 & 3 & 11 & 7 & 26 & 54 & 102 \\
\hline Alosa sapidissima* & 0 & 0 & 1 & 5 & 5 & 43 & 54 \\
\hline Genyonemus lineatus & 0 & 0 & 2 & 0 & 31 & 12 & 45 \\
\hline Gambusia affinis* & 3 & 5 & 2 & 0 & 4 & 26 & 40 \\
\hline Lucania parva* & 11 & 10 & 5 & 2 & 4 & 8 & 40 \\
\hline Gasterosteus aculeatus aculeatus & 0 & 0 & 1 & 3 & 8 & 5 & 17 \\
\hline Syngnathus leptorhynchus & 0 & 0 & 0 & 0 & 15 & 1 & 16 \\
\hline Morone saxatilis ${ }^{*}$ & 0 & 0 & 1 & 1 & 9 & 5 & 16 \\
\hline Cymatogaster aggregata & 0 & 0 & 0 & 4 & 9 & 0 & 13 \\
\hline Porichthys notatus & 0 & 0 & 0 & 1 & 5 & 0 & 6 \\
\hline Dorosoma petenense* & 0 & 0 & 0 & 0 & 3 & 2 & 5 \\
\hline Eucyclogobius newberryi & 0 & 0 & 1 & 0 & 1 & 0 & 2 \\
\hline Tridentiger trigonocephalus* & 0 & 0 & 1 & 0 & 0 & 0 & 1 \\
\hline Gillichthys mirabilis & 0 & 1 & 0 & 0 & 0 & 0 & 1 \\
\hline Cottus asper & 0 & 0 & 0 & 1 & 0 & 0 & 1 \\
\hline Total & 138 & 428 & 1080 & 990 & 3731 & 6941 & 13308 \\
\hline
\end{tabular}

Table 3. Mean $( \pm \mathrm{SE})$ salinity (psu), temperature $\left({ }^{\circ} \mathrm{C}\right)$ and tidal differences $(\mathrm{m})$ by month for 6 channels sampled at China Camp Marsh

\begin{tabular}{|c|c|c|c|c|c|c|}
\hline \multirow{2}{*}{ Parameter } & \multicolumn{3}{|c|}{2001} & \multicolumn{3}{|c|}{-2002} \\
\hline & Jul & Oct & Nov & Jan & Mar & May \\
\hline \multicolumn{7}{|l|}{ Mean salinity } \\
\hline Surface & $27.03( \pm 0.16)$ & $29.12( \pm 0.11)$ & $23.63( \pm 0.18)$ & $17.03( \pm 0.15)$ & $17.7( \pm 0.07)$ & $21.93( \pm 0.29)$ \\
\hline Bottom & $27.02( \pm 0.17)$ & $29.12( \pm 0.11)$ & $23.45( \pm 0.33)$ & $16.7( \pm 0.25)$ & $16.62( \pm 0.53)$ & $21.0( \pm 0.17)$ \\
\hline \multicolumn{7}{|l|}{ Mean temperature } \\
\hline Surface & $20.32( \pm 0.24)$ & $17.73( \pm 0.20)$ & $15.73( \pm 0.24)$ & $8.7( \pm 0.18)$ & $12.83( \pm 0.37)$ & $15.75( \pm 0.39)$ \\
\hline Bottom & $19.9( \pm 0.33)$ & $17.6( \pm 0.23)$ & $15.63( \pm 0.27)$ & $8.7( \pm 0.11)$ & $12.45( \pm 0.25)$ & $15.9( \pm 0.42)$ \\
\hline Mean tidal difference & $1.67( \pm 0.22)$ & $2.03( \pm 0.06)$ & $2.20( \pm 0.07)$ & $2.34( \pm 0.12)$ & $1.97( \pm 0.06)$ & $1.47( \pm 0.07)$ \\
\hline
\end{tabular}




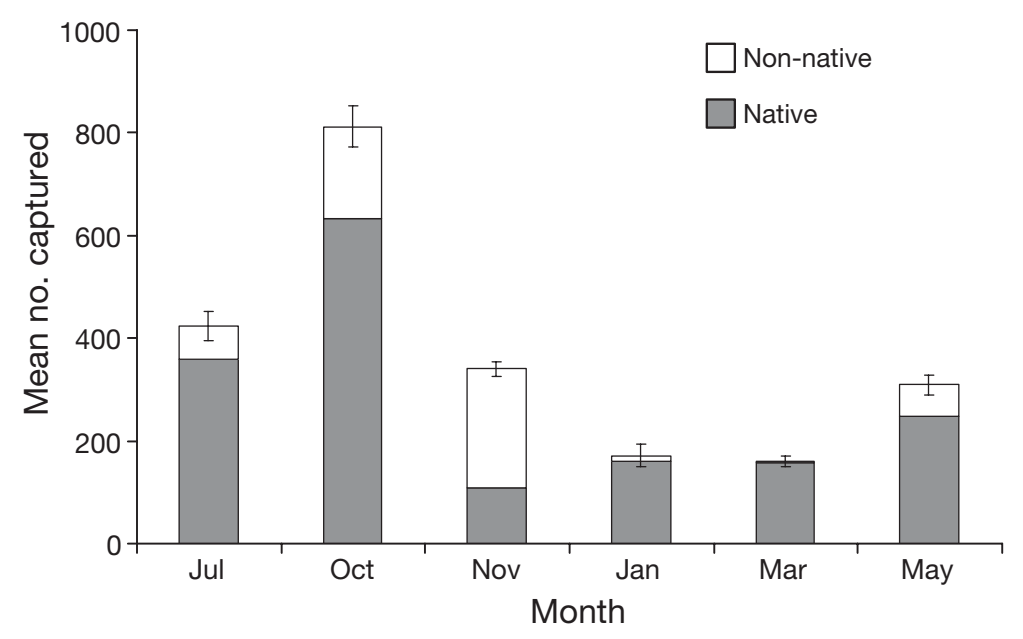

Fig. 2. Total number of native and non-native fishes caught from July 2001 to May 2002 at China Camp Marsh
November, L. armatus (91.4\%) in January, L. armatus $(64.0 \%)$ and C. pallasi $(25.3 \%)$ in March, and E. $\operatorname{mordax}(41.0 \%)$ and L. armatus $(21.0 \%)$ in May (Fig. 3). Species composition varied as a function of channel system order. C. pallasi, shiner surfperch Cymatogaster aggregate, G. lineatus, threespine stickleback Gasterosteus aculeatus, striped bass Morone saxatilis and bay pipefish Syngnathus leptorhynchus were present in high-order channel systems, but rare or absent in first and second-order channel systems.

Fish community composition, in terms of rank order of annual abundance of the top 10 species, was not concordant for any channel order system across time or within a season, but was concordant across channel order systems within each sampling month $(W=0.29,0.33,0.43,0.23,0.51,0.42$, df $=5$, $\mathrm{p}<0.05)$. Kendall's tau rank correlations indicated
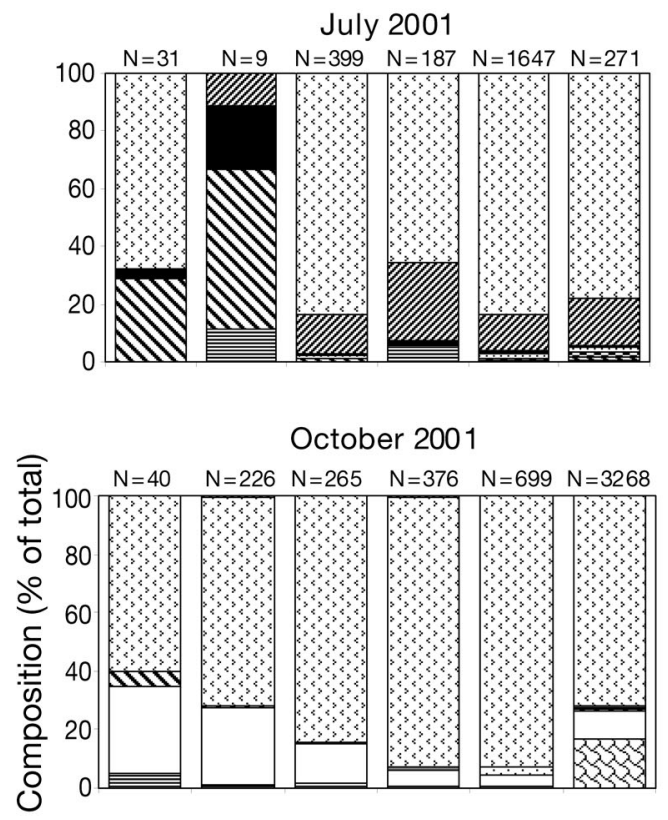

November 2001

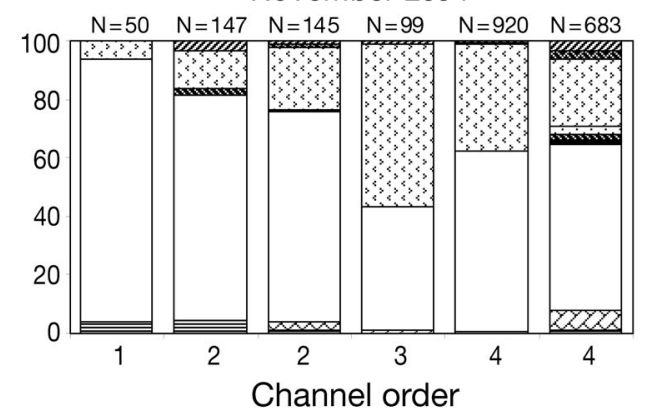

January 2002

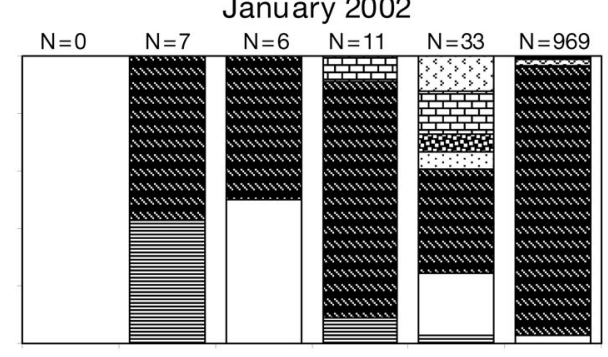

March 2002

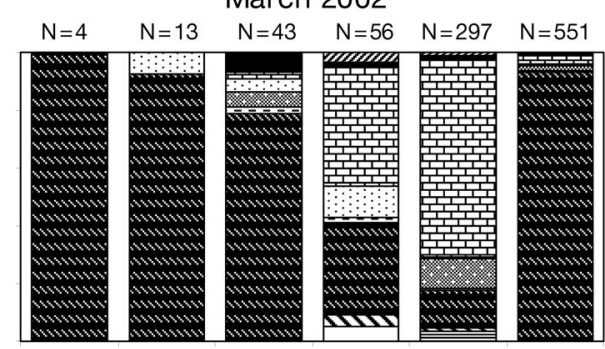

May 2002

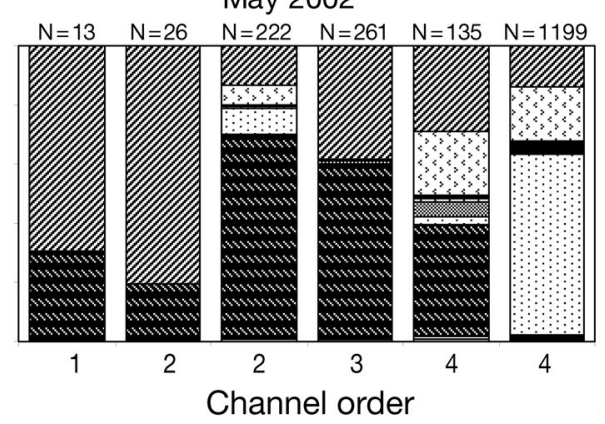

Acanthogbius flavimanus

Alosa sapidissima

Atherinops affinis

Clevelandia ios

臣 Clupea pallasi

門 Cymatogaster aggregata

Dorosoma petenense

$\cdot$ Engraulis mordax

圆 Gambusia affinis

G Gasterosteus aculeatus aculeatus

Genyonemus lineatus

Leptocottus armatus

\$ Luciana parva

$\square$ Menidia beryllina

Morona saxatilis

Syngnatus leptorhynchus

$\forall$ Tridentiger bifasciatus

目 other

Fig. 3. Species composition (\% of total catch) from July 2001 to May 2002 for different channel system orders (first through fourth) at China Camp Marsh. Bold text: non-native species; N: total catch for each channel 
Table 5. Kendall's rank-tau correlation coefficients $(\tau, \mathrm{n}=10)$ for rank order of abundance of fishes between months (A) and between channel orders in (B) October 2001 and (C) May 2002. ${ }^{* *} p<0.01$ and ${ }^{*} p<0.05$ show similar rank order of abundance

\begin{tabular}{|cccccc|}
\hline (A) Month & Oct 2001 & Nov 2001 & Jan 2002 & Mar 2002 & May 2002 \\
Jul 2001 & 0.338 & 0.148 & 0.050 & -0.241 & $0.519^{*}$ \\
Oct 2001 & & $0.605^{*}$ & 0.047 & $-0.568^{*}$ & 0.070 \\
Nov 2001 & & & 0.241 & -0.349 & -0.071 \\
Jan 2002 & & & & 0.400 & 0.361 \\
Mar 2002 & & & & & 0.256 \\
(B) Order & $\mathbf{2}$ & $\mathbf{2}$ & $\mathbf{3}$ & $\mathbf{4}$ & $\mathbf{4}$ \\
1 & $0.794^{* *}$ & $0.676^{*}$ & 0.334 & 0.229 & 0.131 \\
2 & & 0.471 & 0.306 & 0.429 & 0.209 \\
2 & & & 0.501 & 0.057 & 0.157 \\
3 & & & & 0.379 & 0.346 \\
4 & & & & & $0.610^{*}$ \\
(C) Order & $\mathbf{2}$ & $\mathbf{2}$ & $\mathbf{3}$ & $\mathbf{4}$ & $\mathbf{4}$ \\
1 & $1.000^{* *}$ & $0.568^{*}$ & $0.624^{*}$ & 0.555 & 0.262 \\
2 & & $0.568^{*}$ & $0.624^{*}$ & 0.555 & 0.262 \\
2 & & & 0.161 & 0.500 & 0.506 \\
3 & & & & 0.471 & 0.000 \\
4 & & & & & 0.329 \\
\hline
\end{tabular}

averaged 0.086 fishes $\mathrm{m}^{-3}( \pm 0.03)$ in loworder channel systems and 0.029 fishes $\mathrm{m}^{-3}$ $( \pm 0.01)$ in high-order systems, and were significantly influenced by season (wet vs. dry), with higher densities during the dry season in second- and fourth-order channel systems (2-way ANOVA, $F=5.027$, df $=1, \mathrm{p}=0.04$ ), but were not influenced by channel system order. Species-specific differences were also observed. Significantly higher densities of Gambusia affinis in low-order channel systems than in higher-ordered systems $(t=$ 2.308, df = 8.029, p=0.05) (Fig. 5). No significant channel system order differences were found for Menidia beryllina $(t=1.966$, df $=$ 11.122, $\mathrm{p}=0.08)$, Lucania parva $(t=1.664$, df $=14.003, \mathrm{p}=0.12)$, Clevelandia ios $(t=1.366$, $\mathrm{df}=17.532, \mathrm{p}=0.19)$, or Clupea pallasi $(t=-1.512, \mathrm{df}=11.142, \mathrm{p}=0.16)$ were found, although L. parva had highest densities in the first-order channel system, and Atherinops affinis, $M$. beryllina, and C. ios

that, based on rank order of relative abundance, fish communities were similar in July 2001 and May 2002, October 2001 and November 2001, and October 2001 and March 2002 (Table 5A). Rank correlations for October 2001 suggest that the first-order and 2 secondorder channel systems had similar community compositions, as did the 2 fourth-order channel systems (Table 5B). In May 2002, rank correlations revealed that the two fourth-order channel systems had community compositions that were different from the rest of the channel order systems (Table $5 \mathrm{C}$ ). This result suggests that in some (but not all) months, the community composition of low-order channel systems was different from that of high-order systems.

Species richness was greatest in high-order channel systems. Of the 22 species of fishes collected in China Camp Marsh, 7 species were collected from the first-order channel system whereas 19 species came from a fourth-order channel system. Species richness for this site was lowest at the first-order channel system, dominated by Menidia beryllina and Atherinops affinis.

\section{Fish densities}

Tidal prism (TP). Fish densities based on TP $\left(\right.$ no. $\mathrm{m}^{-3}$ ) varied as a function of channel system order and season. There were significantly higher mean annual densities of fishes in low-order channel systems (first- and second-orders) than in high-order systems (third- and fourth-orders) ( $t=$ 2.077, df $=20.037, \mathrm{p}=0.05$ ) (Fig. 4). Fish densities occurred in highest densities in second-order channel systems.

Channel edge. Based on the length of vegetated channel edge, fish density (no. $\mathrm{m}^{-1}$ ) varied seasonally and as a function of channel system order, depending on the species. The mean annual density of fishes in low-order channel systems $\left(0.178 \pm 0.05\right.$ fishes $\left.\mathrm{m}^{-1}\right)$ was not significantly different than in high-order systems $\left(0.145 \pm 0.03\right.$ fishes $\left.\mathrm{m}^{-1}\right)(t=0.597, \mathrm{df}=34$, $\mathrm{p}=0.55$ ) (Fig. 6). Mean annual fish densities of secondand fourth-order channel systems were significantly affected by season (2-way ANOVA, $F=9.102$, df $=1$, $\mathrm{p}=0.007$ ), but not by channel system order.

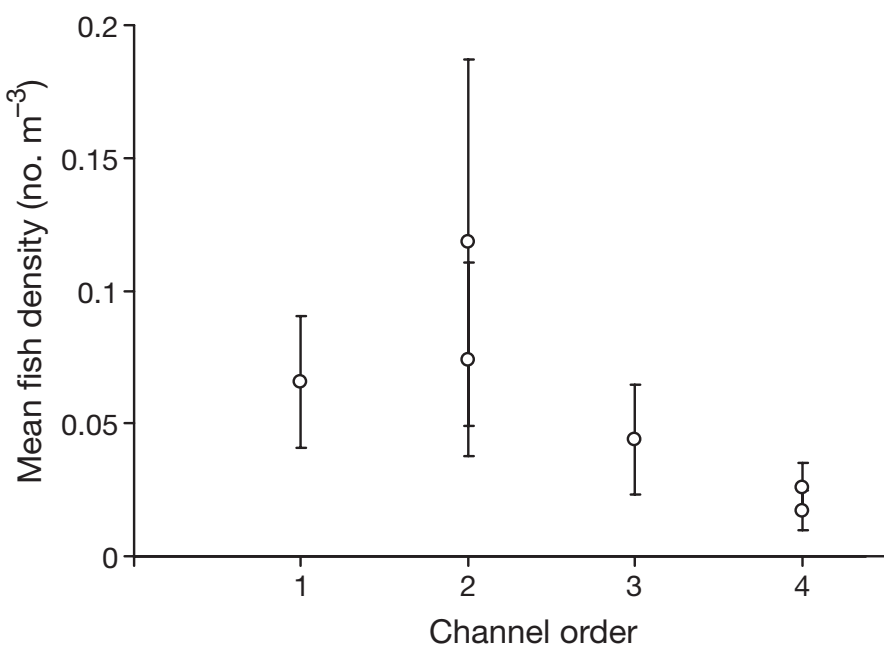

Fig. 4. Annual mean $( \pm \mathrm{SE})$ fish densities based on tidal prism estimates, for each channel order at China Camp Marsh 
However, significantly higher densities $\left(\right.$ no. $\mathrm{m}^{-1}$ ) of Lucania parva were found in low-order channel systems $(t=2.364, \mathrm{df}=15.075, \mathrm{p}=0.03)$ with the highest annual density in the first-order channel system.
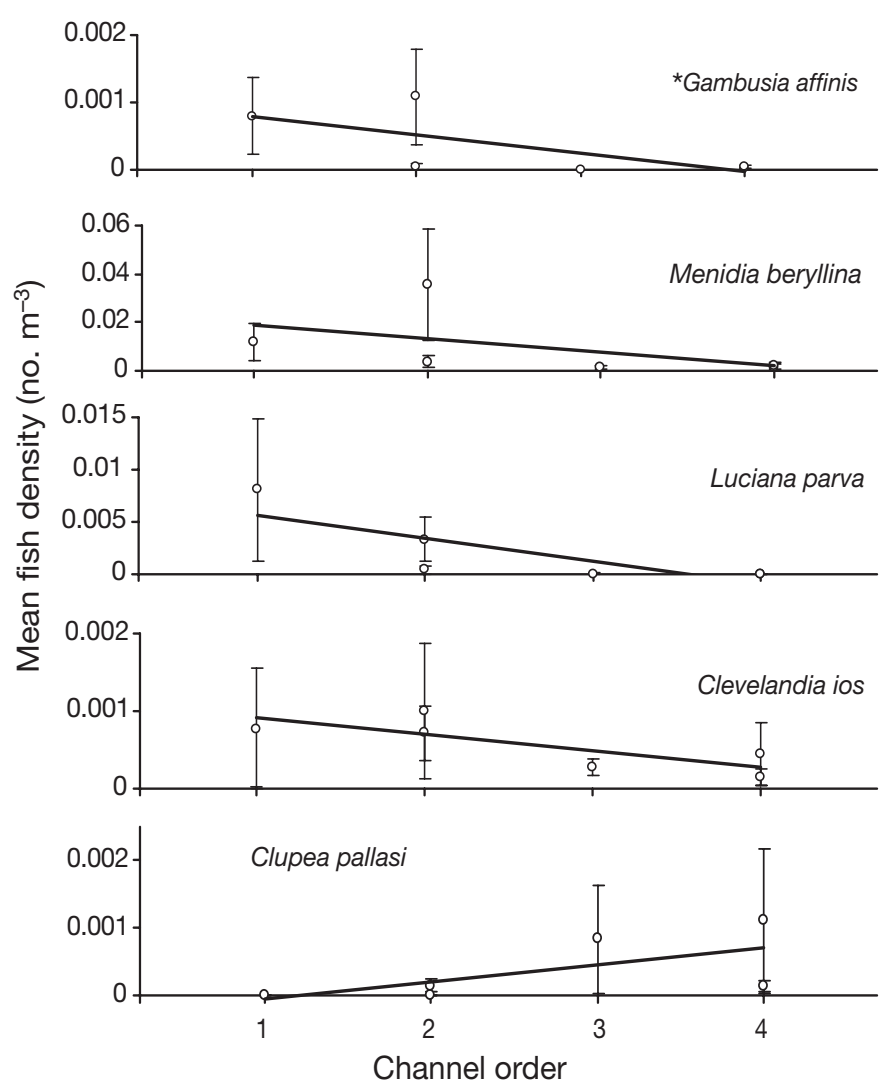

Fig. 5. Gambusia affinis, Menidia beryllina, Lucania parva, Clevelandia ios, and Clupea pallasi. Mean $( \pm \mathrm{SE})$ densities in first- through fourth-order channel systems at China Camp Marsh. * $\mathrm{p}=0.05$

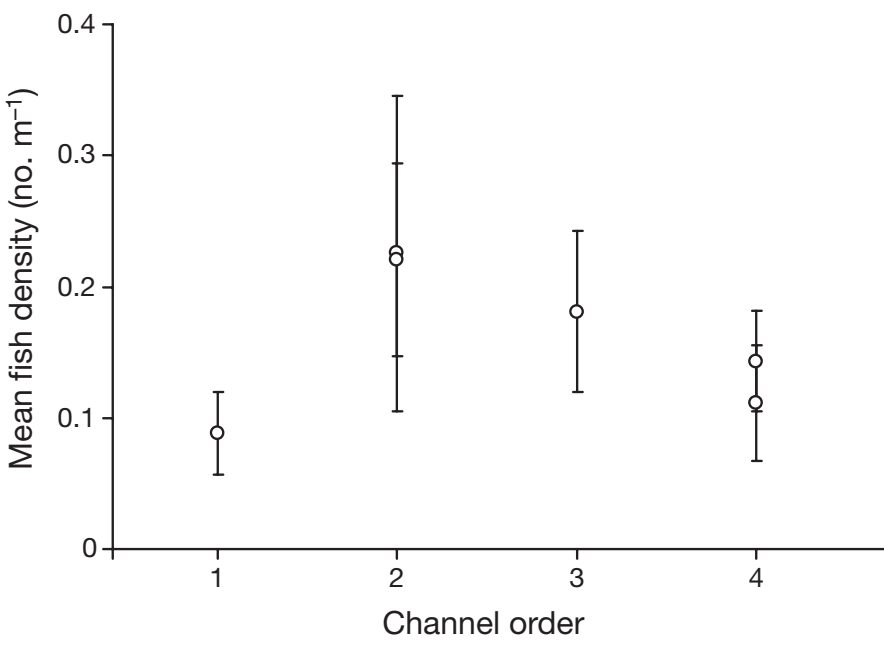

Fig. 6. Annual mean $( \pm \mathrm{SE})$ densities of fishes based on edge estimates $(\mathrm{m})$, for each channel system order at China Camp Marsh
Channel proportions. Species-specific fish densities were correlated to channel proportions. A significant positive correlation was found between density of $\mathrm{Clu}$ pea pallasi and the proportion of fourth-order channel systems than in those from the lower-order systems (Pearson's correlation coefficient $=0.367, \mathrm{df}=30$, $\mathrm{p}=0.05)$.

\section{Stomach content analysis}

Atherinops affinis. Corophium alienense (amphipod), amphipod parts and Nippoleucon hinumensis (cumacean) accounted for $98.9 \%$ of the total prey biomass (Fig. 7A). N. hinumensis was much more common in fish from third- and fourth-order channel systems. The mysid Neomysis kadiakensis was found only in several stomachs from July, whereas $N$. hinumensis was much more common in October and November (Fig. 7B).

Menidia beryllina. Amphipod parts, Corophium alienense, Nippoleucon hinumensis and Delphacidae (hemopterans) comprised $99.0 \%$ of the total prey biomass. Delphacidae were more common in stomachs dissected from $M$. beryllina collected in October than in November (Fig. 7D). N. hinumensis and Delphacidae were more commonly found in stomachs of M. beryllina from the fourth-order channel systems, whereas copepods were more commonly found in stomachs from the low-order systems (Fig. 7C). Neomysis kadiakensis was only found in $M$. beryllina stomachs from fourth-order channel systems.

Leptocottus armatus. The diet of $L$. armatus included more prey species (19) than that of Menidia beryllina(10) and Atherinops affinis (13). Amphipod parts, Traskorchestia traskiana (terrestrial amphipod), Corophium alienense, Neanthes succinea (polychaete), Neomysis kadiakensis (mysid) and Gnorimosphaeroma oregonense (isopod) comprised $94.4 \%$ of their diet. The diet of $L$. armatus in second- through fourthorder channel systems contained a greater variety of prey items than in first-order systems. Of the top 5 prey items, 3 ( $N$. kadiakensis, G. oregonense and $N$. succinea) were not found in $L$. armatus stomachs from the first-order channel system. N. kadiakensis, G. oregonense, N. succinea, and Nippoleucon hinumensis were found in greatest biomasses in stomachs from fourth-order channel systems (Fig. 8A). N. kadiakensis made up a larger percentage of $L$. armatus diet in January than in any other month, whereas T. traskiana made up a larger percentage of the diet in May (Fig. 8B).

Stomach fullness index. The mean stomach fullness index for Leptocottus armatus was greater for highorder than low-order channel systems (2-way ANOVA, 


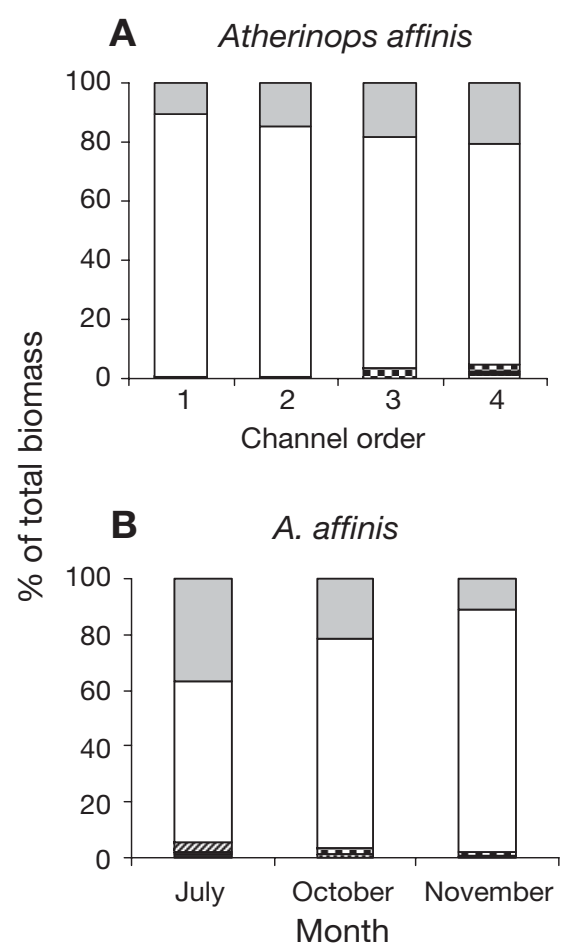

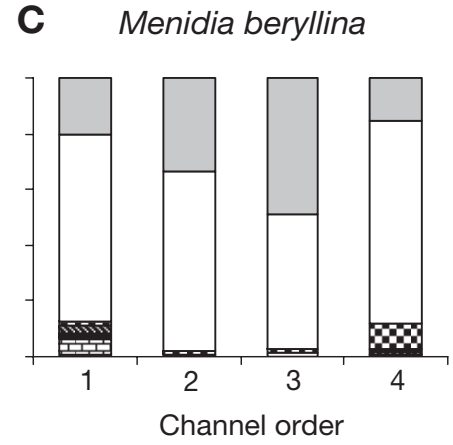

D M. beryllina

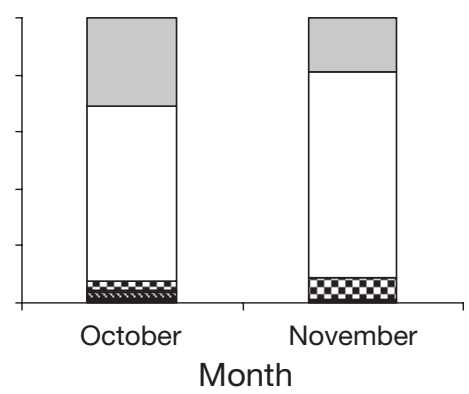

Corophonium alienense

Amphipod parts

\$ Nippoleucon hinumensis

曲 Cumacean parts

Neomysis kadiakensis

Delphacidae

四 Calanoid copepod

Arcatia spp.

Fig. 7. Atherinops affinis and Menidia beryllina. Stomach content composition from July to November 2001 (A. affinis) and October to November 2001 (M. beryllina) as a function of $(\mathrm{A}, \mathrm{C})$ channel system order and $(\mathrm{B}, \mathrm{D})$ month

$F=2.717, \mathrm{df}=3, \mathrm{p}=0.05)$, but not for Atherinops affinis or Menidia beryllina (Table 6). Stomach fullness indices for $L$. armatus also were significantly affected by month (2-way ANOVA, $F=8.218, \mathrm{df}=2, \mathrm{p}<0.01)$ and by the interaction of month and channel system order (2-way ANOVA, $F=2.846, \mathrm{df}=5, \mathrm{p}=0.02)$. Neither month nor channel system order significantly affected the stomach fullness indices of $A$. affinis or $M$. beryllina.

Normalized stomach content weight. Channel system order influenced the total stomach content weights for specific fish species and months, but in no consistent pattern. Normalized stomach contents had greater weights in low-order channel systems for Atherinops affinis in July $(t=3.381, \mathrm{df}=59, \mathrm{p}=0.001)$ and high-order channel systems in October $(t=$ $-3.828, \mathrm{df}=63.828, \mathrm{p}<0.001)($ Fig. 9A,B). Normalized stomach content weights of Menidia beryllina were greatest for fourth-order channel systems when October and November were combined $(t=-2.163$, df $=$ 94.404, $\mathrm{p}=0.03$ ) (Fig. 9C).

Number of prey taxa per fish. Consistent with stomach fullness scores and normalized stomach content weights, no clear pattern existed between channel system order and number of prey taxa per fish. A significant interaction between month and channel system order was noted for Menidia beryllina (2-way ANOVA, $F=3.031, \mathrm{df}=3, \mathrm{p}=0.03$ ) and Atherinops affinis (2-way ANOVA, $F=5.230, \mathrm{df}=6, \mathrm{p}<0.01$ ), but not for month or system order alone (Fig. 10).

\section{DISCUSSION}

Marsh channel heterogeneity, specifically the presence of both low- and high-order channel systems at China Camp Marsh, is necessary to provide essential habitat for early life stages, meet dietary requirements, and enhance species richness of fishes. Although highorder channel systems contain low-order portions, the presence of certain fish species appears to be influenced by physical or temporal differences in access points at the entrance (bay-channel interface) to highand low-order systems. The effect of channel system order was significant for several species during important early life history stages. High-order channel systems supported higher species richness and higher densities of juvenile Clupea pallasi, a commercially important species; however, this result may have been confounded by the smaller size of the low-ordered channel systems compared to the high-order systems. Of the 4 species we collected as juveniles, 3 were native; therefore, incorporating complex channels in restoration projects for tidal salt marshes could enhance adult native fish populations in San Francisco Estuary. 


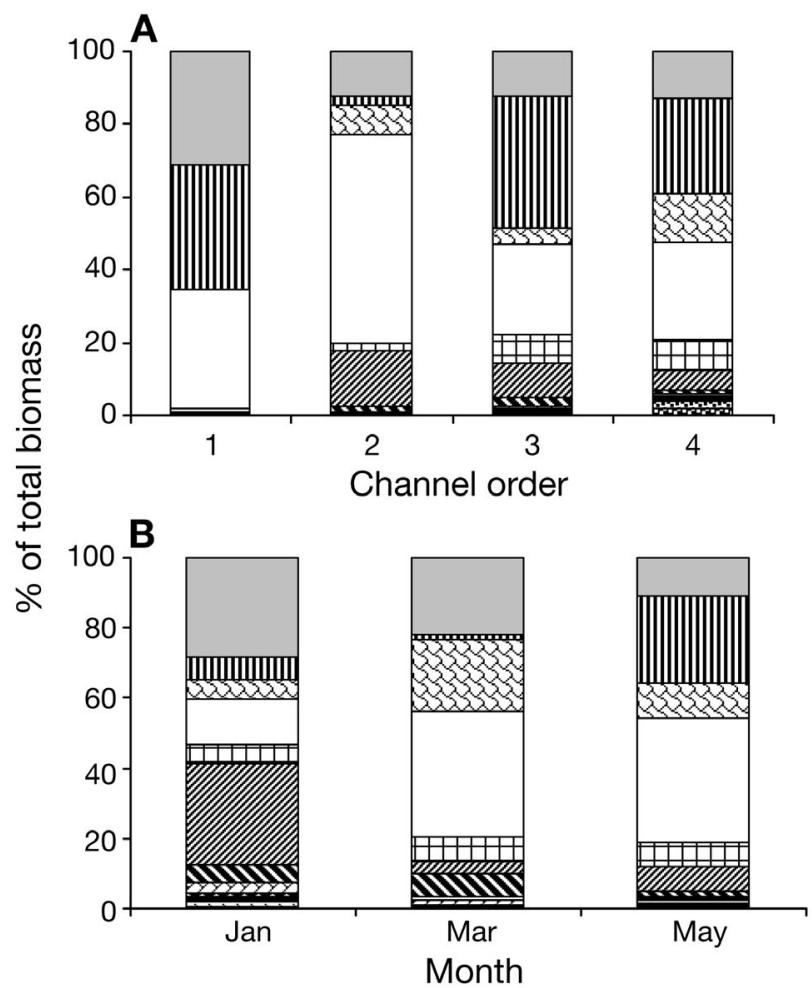

Corophium alienense

m Traskorchestia traskiana

Amphipod parts

Neomysis kadiakensis

四 Neanthes succinea

N Nereidae

$\boxplus$ Gnorimosphearoma oregonense

图 Larval fish

Insect larvae

Sinelobus stanfordii

B Pickleweed

$\$$ Nippoleucon hinumensis

Fig. 8. Leptocottus armatus. Stomach contents composition from January to May 2002 as a function of (A) channel system order and (B) month

\section{Fish community composition}

As well as a greater species richness in high-order channel systems, Desmond et al. (2000) also noted dominance by a few species, and low species richness (8 and 4 species) in first-order channels of 2 southern California tidal salt marshes. In contrast, higher species richness in small (loworder) channel systems has been reported for tidal creek studies on the US east coast (Cain \& Dean 1976, Weinstein 1979) and in Suisun Marsh, San Francisco Estuary (Meng et al. 1994, Matern et al. 2002). The latter studies in Suisun Marsh reported higher species richness in small deadend sloughs than in larger sloughs, although sampling efficiency may have decreased in larger sloughs.

Although species richness at China Camp was lower in low-order channel systems, fish densities were higher. This result is consistent with those of other studies, which found that small sloughs supported higher fish abundances in Suisun Marsh (Meng et al.
1994, Matern et al. 2002) and that rivulets had both higher abundances and biomasses than larger channels (Rozas et al. 1988). It is important to note that sloughs and rivulets have different geomorphic char-

Table 6. Atherinops affinis, Menidia beryllina, and Leptocottus armatus. Mean $( \pm \mathrm{SE})$ stomach fullness scores for fishes collected from 4 different channel orders in China Camp Marsh

\begin{tabular}{|c|c|c|c|c|}
\hline \multirow[t]{2}{*}{ Order } & \multicolumn{3}{|c|}{$2001 \longrightarrow$} & \multirow[t]{2}{*}{ Total } \\
\hline & Jul & Oct & Nov & \\
\hline \multicolumn{5}{|l|}{ A. affinis } \\
\hline 1 & $1.33( \pm 0.33)$ & $1.22( \pm 0.55)$ & $3.00( \pm 1.00)$ & $1.52( \pm 0.32)$ \\
\hline 2 & $2.00( \pm 0.38)$ & $1.05( \pm 0.22)$ & $2.13( \pm 0.29)$ & $1.60( \pm 0.18)$ \\
\hline 3 & $1.44( \pm 0.50)$ & $1.73( \pm 0.50)$ & $1.25( \pm 0.31)$ & $1.50( \pm 0.27)$ \\
\hline 4 & $0.44( \pm 0.11)$ & $2.07( \pm 0.24)$ & $2.33( \pm 0.35)$ & $1.38( \pm 0.15)$ \\
\hline \multicolumn{5}{|l|}{ M. beryllina } \\
\hline 1 & & $1.43( \pm 0.30)$ & $1.14( \pm 0.14)$ & $1.29( \pm 0.16)$ \\
\hline 2 & & $1.13( \pm 0.21)$ & $1.27( \pm 0.18)$ & $1.19( \pm 0.15)$ \\
\hline 3 & & $0.83( \pm 0.17)$ & $0.78( \pm 0.15)$ & $0.80( \pm 0.11)$ \\
\hline 4 & & $1.85( \pm 0.42)$ & $1.42( \pm 0.19)$ & $1.54( \pm 0.18)$ \\
\hline & & -2002 & & \\
\hline \multicolumn{5}{|l|}{ L. armatus } \\
\hline 1 & 0.00 & $1.00( \pm 0.00)$ & $3.00( \pm 0.00)$ & $1.67( \pm 0.42)$ \\
\hline 2 & $2.00( \pm 0.58)$ & $3.07( \pm 0.27)$ & $3.10( \pm 0.31)$ & $2.84( \pm 0.21)$ \\
\hline 3 & $2.71( \pm 0.42)$ & $1.57( \pm 0.40)$ & $3.43( \pm 0.30)$ & $2.57( \pm 0.27)$ \\
\hline 4 & $1.73( \pm 0.22)$ & $2.14( \pm 0.31)$ & $2.50( \pm 0.25)$ & $2.12( \pm 0.16)$ \\
\hline
\end{tabular}



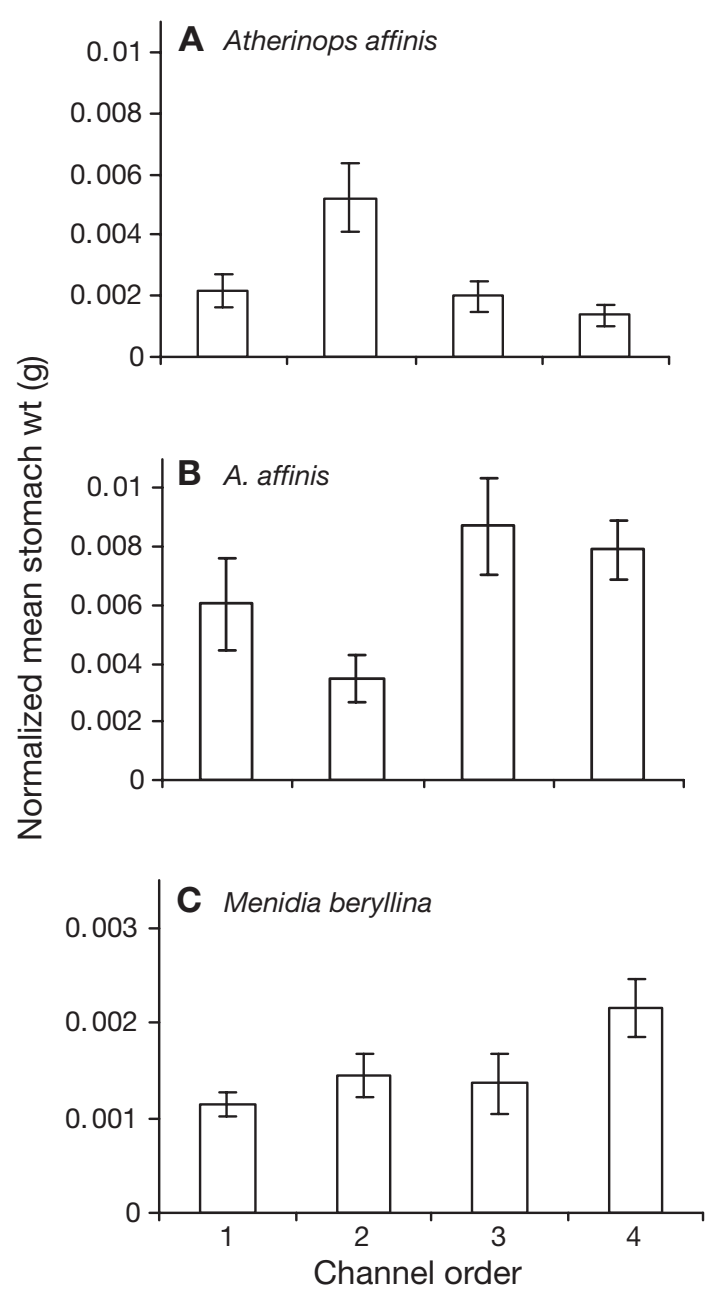

Fig. 9. Atherinops affinis and Menidia beryllina. Mean $( \pm \mathrm{SE})$ normalized stomach content weight as a function of channel system order in (A) July and (B) October 2001 for A. affinis and in (C) October + November 2001 for M. beryllina

acteristics than dendritic tidal channel systems, making direct comparisons difficult. Distributary sloughs are interconnecting and fluvially dominated, whereas rivulets are minute first-order channels, and dendritic channel systems are tidally dominated networks that drain discrete marsh systems. Nonetheless, some similarities in differential habitat utilization can be seen in varied systems.

Native fish species at China Camp Marsh were numerically dominant, and the proportion of native and introduced species did not correspond to channel system order in any month, except in November, when introduced species were more common in low-order channel systems than in large systems. Hieb \& DeLeon (2000) found first- and second-order channels in San Pablo Bay to be dominated by native resident species, and in another regionally-relevant study, native species were reported to dominate small, dead-end sloughs in brackish Suisun Marsh (Moyle et al. 1986, Meng et al. 1994). Dendritic tidal channel systems are important habitat for native fish species, perhaps due to physiochemical conditions or characteristics specific to tidal channel systems.

\section{Tidal channel geomorphology}

The importance of channel geomorphology, including edge, bank slope and access to the marsh surface as important determinants of nekton distributions in tidal salt marshes has been well documented (Rozas 1992, Baltz et al. 1993, Rozas \& Reed 1993, Peterson \& Turner 1994, Rozas 1995, Williams \& Zedler 1999, Rozas \& Zimmerman 2000, West \& Zedler 2000). In our study, channel length, amount of edge, drainage area and TP all increased with increasing channel system order (Table 1). Although these metrics are autocorrelated and therefore not independent, they are all useful for evaluating the relationship between fish densities and geomorphic data.

Bank slopes were steepest in the first-order channel system and decreased with increasing channel system order, as reported for channel systems in southern California (Williams \& Zedler 1999). The percentage of time China Camp channel systems were flooded on an annual basis increased with increasing channel system order, although 1 of the second-order channel systems flooded as frequently as the largest fourth-order channel system. The percent of time that the marsh plain was flooded in the channel systems we studied varied inconsistently with channel order.

\section{Fish abundances}

Gambusia affinis and Lucania parva were found in highest densities (based on both TP and edge) in the first-order channel system, indicating that characteristics associated with low-order channel systems (i.e. steep bank slopes, close proximity to edge, greater access to the marsh surface) are beneficial to certain resident fish species. Greater use of shallow habitats by G. affinis and L. parva is further confirmed by positive correlations between fish density and proportions of first-order channels in all systems. East coast and southern California congeners of L. parva also are more abundant in rivulets and creek tributaries (Rozas et al. 1988, Hettler 1989, Rozas 1992, West \& Zedler 2000) and shallow channels with gradually sloping banks (McIvor \& Odum 1988, Williams \& Zedler 1999) than in other habitats. Similarly, Fundulus parvipinnis, common in southern California tidal marshes, dominated first-order communities; juveniles represented 

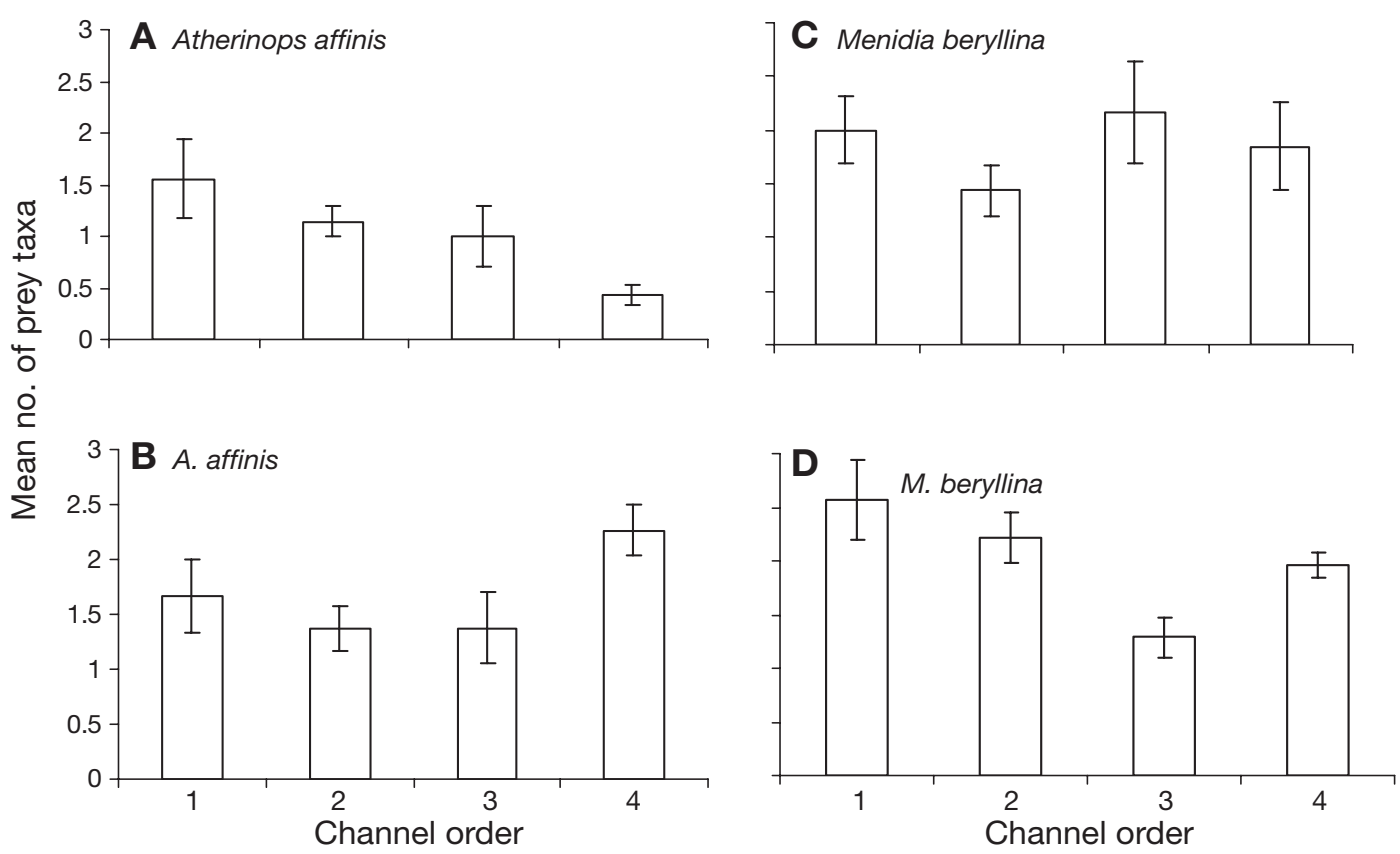

Fig. 10. Atherinops affinis and Menidia beryllina. Mean $( \pm \mathrm{SE})$ number of prey taxa per fish as a function of channel system order in (A) July and (B) November 2001 for A. affinis and in (C) October and (D) November 2001 for M. beryllina

higher proportions in first-order creeks (Desmond 1996, Desmond et al. 2000). The first-order channel system at China Camp had steeper slopes than higher ordered channel systems; we suggest that the shallow environments and close proximity to the vegetated edge (Baltz et al. 1993) account for their high densities in these channel systems.

Atherinops affinis and Menidia beryllina were common in all channel systems at China Camp Marsh and, along with Clevelandia ios, showed a weaker association with channel system order than Gambusia affinis and Lucania parva. A. affinis, M. beryllina and C. ios occurred in highest densities in the second-order channel system that was bordered by the steepest bank slope, and experienced a flooding percentage equal to the largest fourth-order system. Desmond et al. (2000) reported that $A$. affinis and $C$. ios in southern California sites were rare in low-order creeks and more abundant in third- and fourth-order creeks. Further, these populations of $A$. affinis have been found in greater abundance in deep, higher velocity channels (Williams \& Zedler 1999, West \& Zedler 2000). These comparisons demonstrate that some differences exist between study sites, sampling technique, or a combination of these factors.

Differences between our findings and those of other studies may be the result of general undersampling in smaller channel systems, particularly with regard to gobies, which tend to burrow into the mud. Alternatively, the channel systems at China Camp are influ- enced by nearby headwaters, and may therefore experience less oxygen depletion than low-order channel systems in other studies which, when sectioned off from larger channel systems, experience greater oxygen depletion. Moreover, the marsh plains in secondorder channel systems at China Camp had lower elevations and were therefore flooded longer than in other systems. As found in other nekton studies in coastal marshes, a proportionally higher use of secondorder channel systems by Atherinops affinis and Menidia beryllina in our study may be attributable to a steeper bank slope and close proximity to the vegetated edge (Baltz et al. 1993), or lower elevation and longer marsh plain access (Rozas \& Reed 1993, Rozas 1995, Rozas \& Zimmerman 2000, West \& Zedler 2000).

The distribution of juvenile fishes was influenced by channel system order. Juvenile Clupea pallasi (mean total length $=2.80 \pm 0.05 \mathrm{~cm}$ ), present from January through May, were more dense in high-order channel systems (highest densities in the third and fourth-order channel systems) and rare or absent in low-order channel systems. Significant positive correlation of C. pallasi density with the proportion of fourth-order channel systems indicates greater utilization of more complex systems (i.e. wider, deeper channels).

Shallow intertidal creeks have often been considered nursery grounds for larval and juvenile fishes (Shenker \& Dean 1979, Weinstein 1979, Bozeman \& Dean 1980, Rozas \& Hackney 1984), but this does not seem to be the case at China Camp Marsh. Weinstein 
(1979) suggested that nekton first occupy the upper reaches of marshes during recruitment. First-order channels made up $38.0 \%$ ( \pm 0.01$)$ of the largest channel order systems studied at China Camp. Clupea pallasi at China Camp may utilize complex high-order systems with gradual bank slopes, greater amount of edge, or greater access to low-order interior portions. Although our data cannot test this hypothesis directly, other studies of similar systems and species can provide a network with which to make comparisons and conclusions.

Juvenile Engraulis mordax, Genyonemus lineatus and Morone saxatilis displayed disproportionate distributions in high-order channel systems, similar to those for Clupea pallasi. These findings suggest that larger channel systems provide an important habitat for some juvenile fish species.

Providing additional important habitat for early life stages of native and commercially important fish species can enhance populations in San Francisco Estuary. Since 3 of the 4 species collected as juveniles in our study are native and 1 (Clupea pallasi) is commercially important, direct benefits of tidal marsh as a nursery habitat in San Francisco Estuary can be suggested. However, growth, movement, and survivorship were not measured in our study, thus limiting our ability to specifically define the role of channel systems as a nursery habitat (Beck et al. 2001).

\section{Diet composition}

The general diet compositions of Atherinops affinis (Wang 1986, Coyer \& Hall 1993, Barry et al. 1996, Logothetis et al. 2001), Menidia beryllina (Darnell 1958, Dixon 1974, Stickney \& McGeachin 1978, Wang 1986) and Leptocottus armatus (Jones 1962, Levy \& Levings 1978, Smith 1980, Wolf et al. 1983, Wang 1986, Armstrong et al. 1995) are well described, but few studies have compared the relative contribution of marshes (versus open water) to nekton diet (Gray et al. 2002, Laffaille et al. 2002), and none have analyzed systematic variations in prey composition across a gradient of channel system order. Logothetis et al. (2001) described $A$. affinis as a surface-schooling omnivore with a diet dominated by benthic crustaceans (i.e. Corophium alienense), which is consistent with previous studies (Coyer \& Hall 1993, Logothetis et al. 2001). Green macroalgae are also commonly found in the stomachs of adult $A$. affinis (Coyer \& Hall 1993, Barry et al. 1996, Logothetis et al. 2001), yet none were found in its stomachs during our study, probably due to the smaller size classes of $A$. affinis we collected. The components of $A$. affinis' diet were not affected by channel system order, although we found Nippoleucon hinu- mensis (cumacean) in much greater biomasses in stomachs of $A$. affinis collected from third- and fourth-order systems.

The dietary components of Menidia beryllina were not significantly affected by channel system order, although copepods were more commonly consumed in the first-order system and Nippoleucon hinumensis in the fourth-order systems. $M$. beryllina is often classified as a pelagic planktivore (Wang 1986), but it is also known to be an opportunistic omnivore, feeding primarily on copepods, amphipods, and mysids (Darnell 1958, Dixon 1974, Stickney \& McGeachin 1978). This pattern is consistent with our findings. The diet compositions of Atherinops affinis and $M$. beryllina suggest that they consume similar prey items, as availability permits. Small differences in their diets suggest that different channel system orders and their emergent characteristics may provide specific prey items with different quality habitats (Barry et al. 1996).

Leptocottus armatus has been reported to be an omnivorous demersal resident species consuming a variety of crustaceans (including Corophium spp.), polychaetes and various benthic organisms, depending on fish size (Jones 1962, Levy \& Levings 1978, Smith 1980, Wolf et al. 1983, Armstrong et al. 1995). Our study demonstrated that $L$. armatus had a diet more diverse than Atherinops affinis and Menidia beryllina. Stomach fullness indices were significantly related to channel system order (prey taxa richness was greatest in second- through fourth-order channel systems), indicating that this resident fish species may find relatively better resource availability in higher ordered channel systems.

Barry et al. (1996), on the other hand, reported that Leptocottus armatus had the least diverse diet of all fishes collected in Elkhorn Slough, California. While Barry et al. (1996) did not explicitly examine attributes of different tidal channel systems, they found that mean prey richness and number of prey taxa per predator decreased in Elkhorn Slough marsh interior as distance from the ocean increased. The fishes and channel systems sampled at China Camp were adjacent to open water (San Pablo Bay), but much farther from the coastal ocean than the channel systems sampled at Elkhorn Slough by Barry et al. (1996). Our results differ from those of Barry et al. (1996) in that fullness indices, normalized stomach content weight, and number of prey taxa for Atherinops affinis, Menidia beryllina and $L$. armatus varied significantly but inconsistently seasonally and by channel system order.

Normalized stomach content weights in Menidia beryllina were significantly greater in fourth-order channel systems, and prey taxa richness was higher in low-order channel systems. High densities of $M$. beryllina in second-order channel systems, coupled with 
higher prey taxa richness, suggest utilization of high prey taxa richness (low-order channel systems) over high prey abundances (higher-order channel systems). Second-order channel systems at China Camp had the lowest elevations and longest marsh plain flooding durations. In southern California, Fundulus parvipinnis with access to the marsh surface had 6 times more food in their stomachs than those without access (West \& Zedler 2000). In our study, $M$. beryllina had higher stomach content weights in high-order channels (less marsh plain access), suggesting that either this species does not exploit resources on the marsh surface, or access time was not significantly longer in secondorder channels to produce noticeable increases in stomach fullness or stomach content weights. Differences between Atherinops affinis, M. beryllina and Leptocottus armatus employing these measures of habitat use (e.g. based on diet) imply species-specific responses to prey abundance and prey taxa richness, both of which were affected by channel system order.

\section{Implications for restoration}

A number of authors have recommended that firstorder channels be included in Pacific coast restoration projects (Havens et al. 1995, Zedler et al. 1997, Williams \& Zedler 1999, Talley 2000). Desmond et al. (2000) suggested incorporating first-order creeks into restoration sites to increase the availability of both shallow habitat for resident fish species and nursery habitat. Our results from China Camp Marsh support this recommendation. Low-order channel systems in our study supported higher total fish densities and provided essential habitat for Gambusia affinis and Lucania parva. Although Atherinops affinis, Menidia beryllina and Clevelandia ios were collected in all the channel systems we sampled, they were in highest densities in the second-order channel systems with the steepest bank slope and a channel flooding percentage equal to the largest fourth-order systems. These observations suggest that proximity to edge and marsh plain access are important channel system characteristics for these species.

High-order channel systems supported greater species richness than low-order systems and provided a critical habitat for juvenile Clupea pallasi, as well as Engraulis mordax, Genyonemus lineatus and Morone saxatilis. The high-order channel systems in our study region were complex, containing large proportions of first-order channels in their interiors. The amount of time fishes have access to the marsh plain varies considerably, depending upon tidal regime. For example, marsh inundation (habitat availability) can range from $68 \%$ in low-elevation Spartina alterniflora marshes in
Louisiana (Rozas \& Reed 1993), to $33 \%$ in S. alterniflora marshes in North Carolina (Hettler 1989) to less than $10 \%$ in southern California (Desmond et al. 2000, and our study). The species listed above may have entered high-order channel systems to take advantage of more edge or longer flooding duration that provide greater access to the marsh interior. In the case of the largest channel system at China Camp, fish species may seek refuge in deeper pools in the high-order channel portions that do not completely dewater at low tide. Specific geomorphic characteristics at the channel/bay access points appear to govern greater juvenile abundances and species richness in these highorder channel systems. The heterogeneity of such systems, including small interior channels, should be included as critical features in restoration projects. More specifically, the presence of only low-order channel systems may not be sufficient to support high species richness and crucial juvenile habitat. Our study supports the notion that the most desirable marsh structure is one containing a diverse spectrum of both low- and high-order channel systems. Coupling an ecological standpoint and a summary of our findings at China Camp Marsh, development of channel systems representing natural channel networks appears to be critical for successful marsh restoration, particularly in terms of nekton utilization.

Species-specific responses to channel system order may be a direct response to differential distribution or habitat use by prey species. Channel systems of different orders have been shown to provide differential habitat support for prey species such as Nippoleucon hinumensis and copepod species. Our findings support these recommendations, in that low-order and highorder channel systems contribute important yet different habitat functions for tidal marsh fishes.

\section{CONCLUSIONS}

Species composition, abundance and diet of fishes at China Camp Marsh, San Francisco Estuary, were related to channel system order in species specific ways. Gambusia affinis and Lucania parva were more abundant in the first-order channel system. Although results were not significant, second-order channel systems supported higher densities of Atherinops affinis, Menidia beryllina and Clevelandia ios. High-order (third- and fourth-order) channel systems supported greater species richness and densities of juveniles, (comprising Clupea pallasi, Engraulis mordax, Genyonemus lineatus and Morone saxatilis) than low-order systems. Different channel systems may provide optimal habitat for certain prey species (i.e. Nippoleucon hinumensis were more common in third- and fourth- 
order channel systems whereas copepod species were more common in the first-order system), and fish diet displayed species-specific responses to channel system order. Habitat heterogeneity is an important consideration in restoration projects. Inclusion of both loworder channel systems with steep bank slopes and high-order channel systems with gradual slopes and complex interior portions is necessary to maximize habitat for a diverse fish community.

Acknowledgements. This project was funded by CALFED through Cooperative Agreement No. 00FC200021/99B13 between the University of Washington (subcontractor San Francisco State University and the Romberg Tiburon Center for Environmental Studies) and the US Bureau of Reclamation. We thank A. Federline Dean, S. Avent, J. Bills, J. Dorman, D. Gewant, R. Hooff, T. Ignoffo, T. Johnson, H. Kerkering and K. Papastephanou for field assistance. Generous assistance with data analysis was provided by R. Larson. We thank J. Toft for help with invertebrate identification and general stomach content analysis procedures. Geomorphic data were provided by Phillip Williams and Associates, and our special thanks to N. Garrity for TP estimates and assistance. T. Foschi provided help with geographically corrected photographs. Advice from D. Reed and M. Orr helped mold this project in its early stages.

\section{LITERATURE CITED}

Armstrong JL, Armstrong DA, Mathews SB (1995) Food habits of estuarine staghorn sculpin, Leptocottus armatus, with focus on consumption of juvenile Dungeness crab, Cancer magister. Fish Bull (Wash DC) 93:456-470

Baltz DM, Rakocinksi C, Fleeger JW (1993) Microhabitat use by marsh-edge fishes in a Louisiana estuary. Environ Biol Fish 36:109-126

Barletta M, Barletta-Bergan A, Saint-Paul U, Hubold G (2003) Seasonal changes in density, biomass, and diversity of estuarine fishes in tidal mangrove creek of the lower Caeté Estuary (northern Brazilian coast, east Amazon). Mar Ecol Prog Ser 256:217-228

Barry JP, Yorlavich MM, Calliet GM, Ambrose DA, Antrim BS (1996) Trophic ecology of the dominant fishes in Elkhorn Slough, California, 1974-1980. Estuaries 19:115-138

Beck MW, Heck KL, Able KW, Childers DL and 9 others (2001) The identification, conservation, and management of estuarine and marine nurseries for fish and invertebrates. BioScience 51:633-641

Bottom DL, Jones KK, Cornwell TJ, Gray A, Simenstad CA (2005) Patterns of Chinook salmon migration and residency in the Salmon River estuary (Oregon). Estuar Coast Shelf Sci 1:79-93

Bozeman DL Jr, Dean JM (1980) The abundance of estuarine larval and juvenile fish in a South Carolina intertidal creek. Estuaries 3:89-97

Brown LR (2003) Will tidal wetland restoration enhance populations of native fishes? S Francisco Estuar Watershed Sci $1: 1-42$

Cain RL, Dean JM (1976) Annual occurrence, abundance, and diversity of fish in a South Carolina tidal creek. Mar Biol 36:369-379

Chotkowski M (1999) List of fishes found in San Francisco Bay-Delta shallow water habitats. Interag Ecol Program
Newsl 12:12-18

Coats RN, Williams PB, Cuffe CK, Zedler JB, Reed D, Watry SM, Noller JS (1995) Design guidelines for tidal channels in coastal wetlands. Report for US Army Corp of Engineers Waterways Experiment Station, Vicksburg, MS

Coyer JA, Hall SJ (1993) Predation on small anchovy (Engraulis mordax) by large silversides (Atherinidae). Calif Fish Game 79:82-84

Darnell RM (1958) Food habits of fishes and larger invertebrates of Lake Ponchartrain, Louisiana, an estuarine community. Publ Inst Mar Sci Univ Tex 5:353-416

Desmond JS (1996) Species composition and size structure of fish assemblages in relation to tidal creek size in southern California coastal wetlands. MS thesis, San Diego State University, CA

Desmond JS, Zedler JB, Williams GD (2000) Fish use of tidal creek habitats in two southern California salt marshes. Ecol Eng 14:233-252

Dixon CA (1974) A study of food habits of two species of silverside, Menidia beryllina (Cope) and Membras martinica (Valenceinnes), in Upper Galveston Bay, Texas. MS thesis, Texas A\&M University, College Station, TX

Gray A, Simenstad CA, Bottom DL, Cornwell TJ (2002) Contrasting functional performance of juvenile salmon habitat in recovering wetlands of the Salmon River estuary, Oregon, USA. Restor Ecol 10:514-526

Havens KJ, Varenell LM, Bradshaw JG (1995) An assessment of ecological conditions in a constructed tidal marsh and two natural reference tidal marshes in coastal Virginia. Ecol Eng 4:117-141

Hettler WF (1989) Nekton use of regularly-flooded saltmarsh cordgrass habitat in North Carolina, USA. Mar Ecol Prog Ser 56:111-118

Hieb K, DeLeon S (2000) Tidal marsh study. Interag Ecol Program Newsl 13:32-36

Horton RE (1945) Erosional development of creeks and their drainage basins. Bull Geol Soc Am 56:275-370

Jones AC (1962) The biology of the euryhaline fish Leptocottus armatus Girard (Cottidae). Univ Calif Publ Zool 67: 321-367

Jordan F, Babbitt KJ, McIvor CC (1998) Seasonal variation in habitat use by marsh fishes. Ecol Freshw Fish 7:159-166

Kneib RT (1997) The role of tidal marshes in the ecology of estuarine nekton. Oceanogr Mar Biol Annu Rev 35: $163-220$

Kneib RT (2000) Salt marsh ecoscapes and production transfers by estuarine nekton in the southeastern United States. In: Weinstein MP, Kreeger DA (eds) Concepts and controversies in tidal marsh ecology. Kluwer, Dordrecht, p 267-291

Kneib RT, Wagner SL (1994) Nekton use of vegetated marsh habitats at different stages of tidal inundation. Mar Ecol Prog Ser 106:227-238

Laffaille P, Feunteun E, Lefebvre C, Radureau A, Sagan G, Lefeuvre JC (2002) Can thin-lipped mullet directly exploit the primary and detritic production of European macrotidal salt marshes? Estuar Coast Shelf Sci 54:729-736

Levy DA, Levings CD (1978) A description of the fish community of the Squamish River estuary, British Columbia: relative abundance, seasonal changes, and feeding habitats of salmonids. Manuscr Rep Fish Mar Serv Can 1475:1-63

Logothetis EA, Horn MH, Dickson KA (2001) Gut morphology and function in Atherinops affinis (Teleostei: Atherinopsidae), a stomachless omnivore feeding on macroalgae. J Fish Biol 59:1298-1312

Matern SA, Moyle PB, Pierce LC (2002) Native and alien fishes in a California estuarine marsh: twenty-one years of 
changing assemblages. Trans Am Fish Soc 131:797-816

Mathieson S, Cattrijsse A, Costa MJ, Drake P, Elliott M, Gardner M, Marchand J (2000) Fish assemblages of European tidal marshes: a comparison based on species, families and functional guilds. Mar Ecol Prog Ser 204:225-242

McIvor CC, Odum WE (1988) Food, predation risk, and microhabitat selection in a marsh fish assemblage. Ecology 69: 1341-1351

Meng L, Powell JC (1999) Linking juvenile fish and their habitats: an example from Narragansett Bay, Rhode Island. Estuaries 4:905-916

Meng L, Moyle PB, Herbold B (1994) Changes in abundance and distribution of native and introduced fishes of Suisun Marsh. Trans Am Fish Soc 123:498-507

Miller JA, Simenstad CA (1997) A comparative assessment of a natural and created estuarine slough as rearing habitat for juvenile chinook and coho salmon. Estuaries 20:792-806

Minello TJ, Zimmerman RJ (1992) Utilization of natural and transplanted Texas salt marshes by fish and decapod crustaceans. Mar Ecol Prog Ser 90:273-285

Minello TJ, Zimmerman RJ, Medina R (1994) The importance of edge for natant macrofauna in a created salt marsh. Wetlands 14:184-198

Moyle PB, Daniels RA, Herbold B, Baltz DM (1986) Patterns in the distribution and abundance of a non-coevolved assemblage of estuarine fishes. Fish Bull 84:105-117

Orr M, Crooks S, Williams PB (2003) Will restored tidal marshes be sustainable? S Francisco Estuar Watershed Sci $1: 1-33$

Peterson GW, Turner RE (1994) The value of salt marsh edge vs interior as a habitat for fish and decapod crustaceans in a Louisiana tidal marsh. Estuaries 17:235-262

Rozas LP (1992) Comparison of nekton habitats associated with pipeline canals and natural channels in Louisiana salt marshes. Wetlands 12:136-146

Rozas LP (1995) Hydroperiod and its influence on nekton use of the salt marsh: a pulsing ecosystem. Estuaries 18: 579-590

Rozas LP, Hackney CT (1984) Use of oligohaline marshes by fishes and macrofaunal crustaceans in North Carolina. Estuaries 7:213-224

Rozas LP, Minello TJ (1998) Nekton use of salt marsh, seagrass, and nonvegetated habitats in a south Texas (USA) estuary. Bull Mar Sci 63:481-501

Rozas LP, Odum WE (1987a) Fish and macrocrustacean use of submerged plant beds in tidal freshwater creeks. Mar Ecol Prog Ser 38:101-108

Rozas LP, Odum WE (1987b) Use of tidal freshwater marshes by fishes and macrofaunal crustaceans along a marsh stream-order gradient. Estuaries 10:36-43

Rozas LP, Reed DJ (1993) Nekton use of marsh-surface habitats in Louisiana (USA) deltaic salt marshes undergoing submergence. Mar Ecol Prog Ser 96:147-157

Rozas LP, Zimmerman RJ (2000) Small-scale patterns in nekton use among marsh and adjacent shallow nonvegetated areas of the Galveston Bay Estuary, Texas (USA). Mar Ecol Prog Ser 193:217-239

Rozas LP, McIvor CC, Odum WE (1988) Intertidal rivulets and creekbanks: corridors between tidal creeks and marshes. Mar Ecol Prog Ser 99:1-16

Seber GAF, LeCren ED (1967) Estimating population parameters from catches large relative to the population. J Anim Ecol 36:637-643

Editorial responsibility: Otto Kinne (Editor-in-Chief), Oldendorf/Luhe, Germany
Shenker JM, Dean JM (1979) The utilization of an intertidal salt marsh creek by larval and juvenile fishes: abundance, diversity, and temporal variation. Estuaries 2:154-163

Simenstad CA, Cordell JR (2000) Ecological assessment criteria for restoring anadromous salmonid habitat in Pacific Northwest estuaries. Ecol Eng 15:283-302

Simenstad C, Cordell J, Grimaldo L, Higgins H and 5 others (1999) Preliminary results from the Sacramento-San Joaquin Delta breached levee wetland study (BREACH). Interag Ecol Program Newsl 12:15-21

Simenstad CA, Thom RM, Levy DA, Bottom DL (2000) Landscape structure and scale constraints on restoring estuarine wetlands for Pacific coast juvenile fishes. In: Weinstein MP, Kreeger DA (eds) Concepts and controversies in tidal marsh ecology. Kluwer, Dordrecht, p 597-630

Smith JE (1980) Seasonality, spatial dispersion patterns and migration of benthic invertebrates in an intertidal marshsandflat system of Puget Sound, Washington and their relation to waterfowl foraging and for feeding ecology of staghorn sculpin, Leptocottus armatus. PhD thesis, University of Washington, Seattle, WA

Sokal RR, Rohlf FJ (1995) Biometry. The principles and practice of statistics in biological research, 3rd edn. WH Freeman, New York

Stickney RR, McGeachin RB (1978) Food habits of fishes associated with marshland developed on dredged material. Proc Annu Conf SE Assoc Fish Wildl Agencies 32:547-560

Strahler AN (1964) Quantitative geomorphology of drainage basin and channel networks. In: Chow VT (ed) Handbook of applied hydrology, Section 4. McGraw-Hill, New York, p. $39-76$

Szedlmayer ST, Able KW (1996) Patterns of seasonal mobility and habitat use by fishes and decapod crustaceans in a southern New Jersey estuary. Estuaries 19:697-709

Talley DM (2000) Ichthyofaunal utilization of newly-created versus natural salt marsh creeks in Mission Bay, California. Wetlands Ecol Manag 8:117-132

Wang JCS (1986) Fishes of the Sacramento-San Joaquin Estuary and adjacent waters, California: a guide to the early life histories. Interag Ecol Program Tech Rep 9

Weinstein MP (1979) Shallow marsh habitats as primary nurseries for fishes and shellfishes, Cape Fear River, North Carolina. Fish Bull 77:339-357

West JM, Zedler JB (2000) Marsh-creek connectivity: fish use of a tidal salt marsh in southern California. Estuaries 23: $699-710$

Williams GD, Zedler JB (1999) Fish assemblage composition in constructed and natural tidal marshes of southern California: relative influence of channel morphology and restoration history. Estuaries 22:702-716

Williams PB, Orr MK (2002) Physical evolution of restored breached levee salt marshes in the San Francisco Bay Estuary. Restor Ecol 10:527-542

Williams PB, Orr MK, Garrity NJ (2002) Hydraulic geometry: a geomorphic design tool for tidal marsh channel evolution in wetland restoration projects. Restor Ecol 10: $577-590$

Wolf EG, Morson B, Fucik KW (1983) Preliminary studies of food habits of juvenile fish, China Poot Marsh and Potter Marsh, Alaska, 1978. Estuaries 5:102-114

Zedler JB, Williams GD, Desmond JS (1997) Wetland mitigation: can fishes distinguish between natural and constructed wetlands? Fisheries 22:26-28

Submitted: January 19, 2004; Accepted: November 10, 2005

Proofs received from author(s): August 25, 2006 